\title{
El enemigo unitario en el discurso rosista (1829-1852)
}

\author{
Javier Domínguez Arribas \\ École des Hautes Études en Sciences Sociales (EHESS), París
}

\begin{abstract}
Durante el periodo en que Juan Manuel de Rosas fue gobernador de la provincia de Buenos Aires (1829-1852), los propagandistas al servicio de su régimen construyeron un violento discurso contra aquellos considerados como el principal enemigo interior: los unitarios. Este artículo describe en primer lugar las características de dicho discurso, prestando atención a los rasgos físicos y morales que el rosismo atribuyó a los unitarios, a menudo en contraposición a los valores defendidos como propios por el régimen. A continuación se propone una interpretación que subraya las funciones desempeñadas por el discurso anti-unitario, tales como la "simplificación" simbólica del enemigo, la justificación del régimen rosista, el fortalecimiento de la cohesión entre los diferentes grupos que apoyaban a Rosas y la definición, en negativo, de un sentimiento de identidad colectiva.

Palabras ClaVE: Juan Manuel de Rosas, rosismo, discurso, propaganda, unitarios, enemigo, provincia de Buenos Aires, Argentina.

During the period in which Juan Manuel de Rosas was the governor of the province of Buenos Aires (1829-1852), the propaganda-makers of his regime constructed a violent discourse against those considered the main enemy within: the unitaries. First of all, this paper describes the characteristics of this discourse, paying attention to the physical and moral features that Rosas ideology attributed to the unitaries, often by opposition to the values defended as their own by the regime. Next, an interpretation that stresses the functions played by the anti-unitary discourse is proposed. Such functions include the symbolic "simplification" of the enemy, the justification of the Rosas regime, the reinforcement of cohesion among the different groups that supported this system and the definition, in negative terms, of a feeling of collective identity.
\end{abstract}

KEYwords: Juan Manuel de Rosas, the legacy of Rosas, discourse, propaganda, unitaries, enemy, province of Buenos Aires, Argentine.

¡Viva la Confederación Argentina! ¡Mueran los salvajes unitarios! ${ }^{\prime}$

Esta frase resultará sin duda familiar a cualquiera que haya tomado contacto con el periodo en que Juan Manuel de Rosas fue gobernador de Buenos Aires. Tras años de inestabilidad marcados por el enfrentamiento entre dos facciones políticas rivales - los federales y los unitarios-, el llamado "Restaurador de las Leyes" gobernó la provincia de Buenos Aires de 1829 a 1852 (excepto un breve interregno entre 1832 y 1835) con los pode-

1 Lema rosista, 1829-1852. 
res dictatoriales que la Sala de Representantes le había concedido. Apoyándose en un desvirtuado y domesticado partido federal, combatió con dureza a los que consideraba el más peligroso enemigo interior: los unitarios. Para ello, no sólo se valió de unas medidas represivas implacables, sino también del notable aparato de propaganda que había puesto en pie para reforzar su poder. El carácter crítico del periodo y su relativa uniformidad, al menos en lo que respecta a la extrema virulencia de la propaganda rosista, convierten esta etapa en un momento ideal para estudiar el discurso sobre el enemigo interior. ${ }^{2}$

En las páginas que siguen analizaré el discurso que el régimen rosista construyó acerca de los unitarios. Concibiendo el término "discurso" en un sentido muy amplio, prestaré atención no sólo a las ideas transmitidas por la propaganda escrita, sino también a aquéllas difundidas a través de otros medios más accesibles para el conjunto de una población mayoritariamente analfabeta, como el teatro o las distintas celebraciones del régimen. En todo caso, aunque los mecanismos de construcción y difusión del discurso aparecerán en numerosos ejemplos, no centraré mi atención sobre ellos, sino sobre las ideas que transmitieron. ${ }^{3}$ En una primera parte describiré las principales características del discurso anti-unitario para pasar a continuación a interpretar sus funciones más destacadas.

2 La historiografía acerca del periodo rosista es abundante y, a menudo, polémica. Puede señalarse, por ejemplo, Lynch, John: Juan Manuel de Rosas. 1829-1852, Hyspamérica, Buenos Aires, 1986. Una aproximación divulgativa al rosismo, también útil, es la de Malamud, Carlos: Juan Manuel de Rosas, Historia 16, Madrid, 1987. Sobre temas más específicos, son interesantes, entre otros, los trabajos de Myers, Jorge: Orden y virtud. El discurso republicano en el régimen rosista, Universidad Nacional de Quilmes, Buenos Aires, 1995; y "Las formas complejas del poder: la problemática del caudillismo a la luz del régimen rosista”, en Goldman, Noemí y Salvatore, Ricardo (eds.): Caudillismos rioplatenses. Nuevas miradas a un viejo problema, Eudeba, Buenos Aires, 1998, págs. 83-100. Orden $y$ virtud cuenta con una recopilación de documentos que han sido de gran ayuda para la realización de este trabajo. Véanse también los estudios de Salvatore, Ricardo: "Reclutamiento militar, disciplinamiento y proletarización en la era de Rosas", Boletín del Instituto de Historia Argentina y Americana "Dr. Emilio Ravignani", 3. a serie, n. o 5, Buenos Aires, 1992, págs. 25-47; "Fiestas Federales: Representaciones de la República en el Buenos Aires rosista”, Entrepasados, n. ${ }^{\circ} 11$, 1996, págs. 45-68; y “"Expresiones federales': formas políticas del federalismo rosista”, en Goldman y Salvatore (eds.): Caudillismos rioplatenses, págs. 189-222. Acerca de la bibliografía sobre el rosismo, consúltese Quattrocchi-Woisson, Diana: Los males de la memoria. Historia y política en la Argentina, Emecé, Buenos Aires 1995. Las posibilidades de comparar el discurso sobre los unitarios con otras elaboraciones acerca del enemigo interior en contextos históricos diferentes son enormes. Desgraciadamente, no hay espacio en este estudio para hacer explícitos este tipo de paralelismos.

3 Existen ya, además, diversos estudios que se han ocupado de los medios de transmisión del discurso rosista. La prensa y los propagandistas del régimen aparecen tratados, por ejemplo, en Myers: Orden..., págs. 34-44; y en Abad de Santillán, Diego: Historia argentina, Tipográfica Editora Argentina, Buenos Aires, 1965, vol. 2, págs. 439-452 (epígrafe "Periodismo federal y periodismo opositor”). Acerca del papel de la Iglesia, véase Lynch: Rosas..., págs. 176-178. Sobre el rol de los 


\section{Las características del discurso anti-unitario}

En primer lugar, es necesario tener en cuenta que la imagen de los unitarios puesta en circulación por el discurso rosista es una representación simbólica y, por tanto, autónoma respecto a la realidad tangible. La propaganda del régimen construyó, basándose sólo vagamente en el mundo real, un tipo ideal de enemigo interior que nos dice mucho más de sus creadores que de la facción a la que pretendía representar. Se trata, en definitiva, de un "unitario imaginado". ${ }^{4}$ Así, cuando un propagandista del rosismo aludía a los "salvajes unitarios", no tenía por qué referirse necesariamente a los miembros de este partido, ya que la categoría de "unitarios" fue utilizada por el discurso del régimen para uniformar a los diversos enemigos de Rosas — reales o supuestos - bajo una única denominación. "Unitario" se convirtió en un término comodín que permitía englobar a sectores muy distintos: desde los miembros de la Generación de $1837^{5}$ a los jesuitas, pasando por los federales disidentes y por los "auténticos" unitarios. Lo único que tenían en común era ser considerados enemigos por el discurso rosista. "No nos podéis, pues, llamar unitarios del año 26", clamaba Juan Bautista Alberdi, dirigiéndose a Rosas. ${ }^{6}$ Irónicamente, a pesar de su difícil entendimiento con los jefes unitarios emigrados, los miembros de la Asociación de Mayo no se libraron de tal calificativo. Lo mismo ocurrió

festejos federales en la transmisión de la propaganda, Salvatore: "Fiestas...". Para el teatro, véase Castagnino, Raúl H.: El teatro en Buenos Aires durante la época de Rosas, Academia Argentina de Letras, Buenos Aires, 1989 (1. a ed., 1944); y para otros medios de difusión del discurso, como las pulperías, consúltese González Bernaldo, Pilar: "El levantamiento de 1829: el imaginario social y sus implicaciones políticas en un conflicto rural", Anuario IEHS, n. ${ }^{2}$ 2, UNCPBA, Tandil, 1987, págs. 137-176 (sobre las pulperías, pág. 173).

4 Conviene aclarar que no se prestará atención, por lo general, a lo lejos o lo cerca que este "unitario imaginado" se encuentre de la realidad. Ricardo Salvatore y Jorge Myers hacen algunas reflexiones sobre el particular. Salvatore: "Expresiones...”, pág. 218; Myers: Orden..., págs. 56-57.

5 Grupo de intelectuales opuestos a Rosas desde fines de la década de 1830. Se agruparon en la "Asociación de la Joven Generación Argentina", llamada más adelante "Asociación de Mayo". Véase, por ejemplo, Wasserman, Fabio: "La Generación de 1837 y el proceso de construcción de la identidad nacional argentina", Boletín del Instituto de Historia Argentina y Americana "Dr. Emilio Ravignani", 3. ${ }^{\text {a }}$ serie, n. ${ }^{\circ} 15$, Buenos Aires, 1997, págs. 7-34.

6 Alberdi, Juan Bautista: "Confederación Argentina", El Nacional, Montevideo, 15 de enero de 1839, pág. 174. Recogido por Chiaramonte, José Carlos: Ciudades, provincias, Estados: Orígenes de la Nación Argentina (1800-1846), Ariel/Espasa Calpe, Buenos Aires, 1997, pág. 642. Cursiva en el original. Jorge Myers señala que la figura del unitario "serviría para designar a grupos cada vez más amplios y cada vez menos vinculados —en cuanto a su identidad ideológica concreta — al movimiento político de ese nombre. Los miembros de la facción balcarcista en 1833, los rosistas disidentes de 1834, los federalistas disidentes de las provincias en todo el periodo comprendido entre 1829 y 1852 , y la juventud romántica de 1837, todos serían consecutivamente absorbidos por ese único apelativo de unitarios.” Myers: Orden..., págs. 54-55. Véase asimismo Lynch: Rosas..., págs. 217 y 329. 
con Justo José de Urquiza, el caudillo de Entre Ríos, o con los jesuitas, una vez deterioradas sus relaciones con el régimen. Diego Abad de Santillán apunta que los rosistas extendieron por Buenos Aires el siguiente grito: "¡Mueran los jesuitas salvajes unitarios ingratos!”.?

Para referimos a un segundo rasgo del discurso anti-unitario puede sernos útil aludir a otras consignas rosistas. El 13 de abril de 1842, con motivo del aniversario del ascenso de Rosas al poder, se celebró en uno de los teatros de Buenos Aires una función precedida de diversas canciones e himnos patrióticos. Unos días después, el Diario de la Tarde relataba que se habían gritado, entre otras, las fórmulas siguientes: “¡Mueran los inmundos salvajes unitarios pardejón Rivera, manco Paz, imbécil Ferrer y traidor Mascarilla! ¡Mueran todos los inmundos salvajes unitarios!”. ${ }^{8}$ Este ejemplo ilustra el segundo rasgo del que hablábamos: el discurso rosista presentó a ciertos caudillos opuestos al régimen como la personificación de los unitarios (pertenecieran a este grupo o no). La patria no sólo necesitaba héroes, sino también una serie de malvados - de antihéroes- que pudieran representar al conjunto de los enemigos. Fueron sobre todo las figuras de Juan Lavalle (importante en este sentido desde el comienzo del rosismo) y "el pardejón Rivera" las que jugaron este rol a principios de la década de 1840, junto a Paz, Lamadrid y "Mascarilla" López. En los últimos momentos del régimen, el papel pasó al "loco traidor salvaje unitario Urquiza". Sus nombres aparecían frecuentemente en los "mueras", como hemos visto, siempre rodeados de los mismos epítetos, y sus efigies fueron degolladas, ahorcadas y quemadas en numerosas celebraciones. ${ }^{9}$

Una vez examinadas estas características generales, pasemos a analizar los rasgos que la propaganda rosista atribuyó a los unitarios. Veremos en primer lugar unos atributos referidos a la apariencia externa, para seguir con una serie de rasgos morales.

El discurso anti-unitario defendía la posibilidad de reconocer al enemigo unitario a partir de su aspecto exterior. Unos colores (el celeste y el

7 Abad de Santillán: Historia argentina, pág. 354. Los jesuitas habían vuelto al Río de la Plata en 1836, invitados por Rosas. Su neutralidad política motivó su expulsión de la provincia de Buenos Aires en 1843, acusados de unitarios. Lynch: Rosas..., pág. 178. Urquiza, por su parte, al apoyar a Rosas en 1849, reclamaba "el alto honor de combatir siempre a la vanguardia contra el bando rebelde de los salvajes unitarios”. Ibid., págs. 285 y 312. Sobre las diferencias entre la Asociación de Mayo y los unitarios exiliados en Montevideo, véase ibid., pág. 193.

8 Diario de la Tarde, 18 de abril de 1842. En Castagnino: El teatro..., pág. 407.

9 Véanse Lynch: Rosas..., págs. 177 y 197-199; Castagnino: El teatro...; y Salvatore: "Fiestas...", págs. 48 y 52. Más adelante veremos otros ejemplos del papel de estos personajes en el discurso anti-unitario. 
verde), una vestimenta concreta (levita, pantalón, chaleco y bota fuerte) y una forma determinada de afeitarse (ausencia de bigote y "patilla en U") permitían que, según la propaganda rosista, la identificación fuera posible. Una distinción se hacía necesaria. Así, en oposición directa a este "aspecto unitario", el "aspecto federal" se caracterizaba por el uso masivo de otro color (el punzó, próximo al rojo), de otras ropas y distintivos (chiripá, poncho, bota de potro, divisa y cintillo punzó) y de otros adornos faciales en los hombres (patilla alargada y bigote). ${ }^{10}$ En el terreno de las apariencias, ser federal era sobre todo no ser unitario. Este aspecto federal fue regulado detalladamente por distintas normas legales referidas, por ejemplo, al color de la vestimenta o a la forma de bigotes y patillas. Quien no acatara esta tendencia a la uniformidad era tachado de unitario y podía ser enviado a prisión. En los sumarios policiales de la época puede leerse: "no ha prestado ningún servicio a la Federación. Es de chaqueta muy unitaria" o "no usa bigote, es unitario salvaje"." Se consideraba, por tanto, que a través del aspecto externo, de colores, ropas, o simplemente de un tipo de patilla, era posible distinguir a los federales de los unitarios, a los amigos de los enemigos, en suma, a nosotros de los "otros". ${ }^{12}$

Sin embargo, el mayor problema no lo plantea la diferencia visible, sino la ocultación de ésta: "las cosas deberían parecer lo que realmente eran". ${ }^{13}$ La creencia en la posibilidad de que los unitarios se ocultaran, otro elemento presente en el discurso rosista, contradice hasta cierto punto la imagen del enemigo unitario reconocible por su aspecto exterior. Esta concepción aparece a menudo vinculada a la idea de conspiración, que veremos más adelante. El unitario debía ser desenmascarado. ${ }^{14}$

10 Salvatore: "Expresiones...”, págs. 200-201; Lynch: Rosas..., págs. 172-173. En ocasiones, los unitarios eran denominados "los de levita”. Castagnino: El teatro..., pág. 68.

11 Citado en Lynch: Rosas..., págs. 207 y 173, respectivamente. Consúltense también Castagnino: El teatro..., pág. 74; Myers: Orden..., pág. 81, y Abad de Santillán: Historia argentina, pág. 457.

12 Lynch: Rosas..., págs. 173 y 203. Jorge Myers señala que la "uniformidad en la vestimenta y en otras formas de adorno personal (...) iba dirigida a facilitar la identificación de aquellos que apoyaban al régimen y a obligar a aquellos cuya oposición se originaba en cuestiones de principios a descubrirse por su recusación a lo que consideraban una obligación humillante.” Myers: Orden..., pág. 82.

13 Myers: Orden..., pág. 81.

14 No son extrañas las referencias al "enmascaramiento", a la "máscara" o al necesario "desenmascaramiento" de los unitarios. Salvatore apunta, por ejemplo, que una forma de denominarlos era "ocultos con la máscara que conviene a sus logias infernales". Salvatore: "Fiestas...", pág. 50. El mismo autor señala que "debajo del disfraz federal podía siempre ocultarse un unitario". Salvatore: "Expresiones...”, pág. 202. 
Pero, ¿qué rasgos morales definían a los unitarios según el discurso rosista? El carácter "salvaje" del unitario, su "ferocidad", es quizá el más llamativo. ${ }^{15}$ Esta facción era considerada responsable de los crímenes cometidos en la República durante los últimos tiempos, siendo sus dos víctimas más destacadas Manuel Dorrego y Facundo Quiroga. ${ }^{16}$ La expresión "salvajes unitarios" se convirtió en una de las frases más representativas del rosismo y, precedida del "mueran", constituyó un lema de utilización obligatoria. "Salvaje" pasó incluso a significar "unitario", sin necesidad de más explicaciones. ${ }^{17}$ La misma intención de resaltar la brutalidad del enemigo se encuentra detrás de la utilización de otros calificativos como "feroces", "bestias", "bárbaros", "asesinos", "monstruos", "parricidas", etc. ${ }^{18}$ El siguiente texto de Pedro de Angelis, el principal propagandista del rosismo, ilustra a la perfección - y con gran dramatismo- este elemento tan peculiar del discurso rosista:

Los hechos de estos hombres descarriados eran más feroces que sus palabras. Baste decir que los prisioneros fueron enterrados vivos en las fosas que ellos mismos se habían cavado, iy los párvulos, acometidos inhumanamente en los brazos de sus madres violadas! ;Un blandengue, que tuvo la desgracia de caer en manos de soldados de Lavalle, cuyas filas había abandonado, fue mutilado vivo, le abrieron el pecho, y se ungieron el rostro con la sangre que destilaba de su corazón palpitante! ${ }^{19}$

15 Ricardo Salvatore llega a considerar el "salvagismo" [sic] de los unitarios uno de los "elementos claves de la ideología federal". Salvatore: "Fiestas...", pág. 48. Jorge Myers, por su parte, hace referencia a la "ferocidad" y a las "coléricas furias" que el rosismo atribuyó a los unitarios. Sin embargo, la alusión a estas características es sólo superficial, presentándolas como un elemento más de la imaginería catilinaria adoptada por el discurso rosista para hacer el retrato de sus enemigos. Myers: Orden..., pág. 56.

16 Lynch: Rosas..., págs. 152, 158 y 199-200. En su proclama del 13 de abril de 1835, Rosas destacaba que la facción unitaria "ha generalizado los crímenes y garantizado su impunidad". Recogida por Myers: Orden..., págs. 161-163.

17 Véanse los versos Al Retrato de SE, recogidos por Salvatore: "Fiestas...", pág. 67, n. 27.

18 Lynch: Rosas..., págs. 172 y 219-220; Myers: Orden..., págs. 210-211; Salvatore: "Fiestas...", pág. 50; Castagnino: El teatro..., pág. 427. Un manifiesto teatral de 1844, refiriéndose a los unitarios, afirmaba: "no es nuestro ánimo (...) detallar los crímenes, traiciones e infamias de todo género, con que la horda salvaje y parricida ha detenido el vuelo de nuestra patria". Curiosamente, Castagnino, poco sospechoso de simpatías rosistas, apunta que el tono de este manifiesto tiene una "ponderable mesura". Ibid., pág. 432.

19 De Angelis, Pedro: "El General Rosas y los Salvajes Unitarios: Artículo octavo", Archivo Americano y Espíritu de la Prensa del Mundo, n. ${ }^{\circ}$ 12, 31 de mayo de 1844, págs. 334-338. En Myers: Orden..., págs. 202-203. En la serie de documentos recogidos por Myers es posible encontrar muchos otros ejemplos similares: “ $i(.$.$) ese bando funesto, que parece que se hubiera propuesto resumir en el$ corto periodo de su obscura existencia las desgracias de todos los siglos y los crímenes de todos los hombres destinados a afligir la humanidad!”. Rasgos biográficos de la vida pública del Brigadier General Don Juan Manuel de Rosas, Honorable Sala de Representantes, Buenos Aires, 1842, pág. XVI. Recogido por Myers: Orden..., pág. 274. 
Los unitarios eran presentados también como promotores de la anarquía, como agentes del desorden enfrentados a todas las normas establecidas. No era extraño, pues, encontrar en la prensa del momento afirmaciones en las que el partido unitario aparecía como "esa facción soberbia y presuntuosa que promueve con tanta audacia los trastornos y el desorden". ${ }^{20}$ Como promotores del desorden, era inevitable que fueran enemigos de las leyes. En un texto de 1842 se destacaba que los unitarios "profanaban el nombre de las leyes, mientras hacían alarde de violarlas". ${ }^{21}$ En diversas ocasiones, los términos "anarquista" o "anárquico" fueron utilizados como calificativos para referirse a este partido, acompañados de otros..$^{22}$ En definitiva, los unitarios, en tanto que anarquistas, eran, en palabras de Pedro de Angelis, "los mayores enemigos del orden y las leyes". ${ }^{23}$

El salvajismo - visto anteriormente- $-\mathrm{y}$, sobre todo, la promoción de la anarquía, dos imágenes atribuidas por la propaganda rosista a sus enemigos unitarios, se oponen frontalmente a uno de los valores centrales (si no el principal, como propone Myers) defendidos por la retórica del régimen: el orden. La sumisión a las autoridades, el reconocimiento de las jerarquías y el respeto a las leyes habían sido considerados desde siempre por Rosas valores supremos. ${ }^{24}$ Estas creencias pasaron a formar parte del discurso de su régimen, siendo repetidas continuamente por la retórica oficial. Frente a los "anarquistas unitarios" Rosas se convirtió en el "Restaurador de las Leyes". Esta dicotomía entre anarquía y orden, entre crímenes y leyes, entre unitarios y federales, en definitiva, se encuentra formulada explícitamente en las obras de los propagandistas del rosismo. En 1830, una vez que Rosas se encontraba instalado en el poder, Feliciano Sáinz de Cavia señalaba lo siguiente:

20 "Fuera Carafas", El Relámpago: Papel crítico, satírico, epigramático, federal y antianarquista, n. ${ }^{\circ}$ 2, 1 de octubre de 1833, págs. 2-3. Obsérvese el título de esta publicación. En Myers: Orden..., págs. 275-276. Véanse, además, Lynch: Rosas..., págs. 151-152; y Myers: Orden..., págs. 54-55. Salvatore, apunta, por ejemplo, que el discurso rosista consideraba que la República se encontraba "amenazada por la acción disolvente de los anarquistas unitarios". Salvatore: "Fiestas...", pág. 60.

21 Rasgos biográficos de la vida pública del Brigadier General Don Juan Manuel de Rosas, págs. X-XII. Recogido por Myers: Orden..., págs. 273-274.

22 Así, un documento de 1842 citado por Salvatore alude al "Salvage y anárquico vando [sic] de los sacómanos, asquerosos y pérfidos Unitarios". Salvatore: "Expresiones...”, pág. 217.

23 De Angelis, Pedro: "El General Rosas y los Salvajes Unitarios: Artículo sexto", Archivo Americano y Espíritu de la Prensa del Mundo, n. ${ }^{\circ}$ 8, 31 de octubre de 1843, págs. 104-107, en Myers: Orden..., págs. 201-202.

24 Sobre el "sentido del orden en el discurso rosista", véase el epígrafe de igual nombre en Myers: Orden..., págs. 73-84. Acerca de la "obsesión” personal de Rosas por el orden, Lynch: Rosas..., págs. 100,151 y 327. 
La marcha actual de los negocios en esta provincia es el producto del triunfo de la causa del orden sobre la anarquía; de las leyes e instituciones sobre el parricidio y la usurpación; (...); y de los principios más sagrados en el orden social sobre la fuerza liberticida, que los derrocó por medio de un atentado execrable..$^{25}$

Otra característica atribuida frecuentemente por el discurso rosista a los unitarios es la impiedad. Así, el unitario, además de salvaje y anarquista, es considerado un impío, enemigo de Dios, la religión y la Iglesia. Serán comunes las alusiones a los "enemigos de la religión santa del Estado", o a los "enemigos de Dios y de los hombres". ${ }^{26}$ Las medidas anticlericales del gobierno de Rivadavia, de las que se responsabilizaba a los unitarios, constituían para la propaganda rosista la prueba concluyente de su impiedad. Pedro de Angelis alude a estas medidas en uno de sus textos:

(...) y el Gobierno, que proclamaba la libertad de las conciencias, ¡se empeñó en socavar los cimientos de la religión del país! (...). [Los unitarios] llevaron sus manos sacrílegas hasta el santuario. ¡Todo fue desbaratado en un instante: profanados los templos, invadido el tabernáculo, insultados los sacerdotes, dilapidado su patrimonio (...). ${ }^{27}$

Según la retórica de su régimen, Rosas, frente a la irreligiosidad y a las medidas anticlericales de los unitarios, demostró su piedad desde que llegó al poder a través de una política favorable a la Iglesia católica: "el Ilustre Restaurador de las Leyes (...) restableció la dignidad del culto debi-

25 Sáinz de Cavia, Feliciano: "Introducción”, El Clasificador o Nuevo Tribuno, n. ${ }^{\circ}$ 1, 6 de julio de 1830. Recogido por Myers: Orden..., págs. 209-210.

26 Véanse Salvatore: "Fiestas...”, pág. 50; y la felicitación a Rosas de Quiroga Sarmiento, obispo de Cuyo, por la destrucción de "la horda inmunda de los unitarios" (1835). Citado por Abad de Santillán: Historia argentina, pág. 285. Otros apelativos en la misma línea son "enemigos implacables de nuestro Dios y nuestras leyes" o "enemigos declarados de Dios, de los hombres, de la religión y de

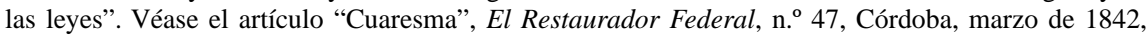
págs. 192-193. En Myers: Orden..., págs. 286-287. En el Manifiesto de la empresa teatral VelázquezMachado (1844), por ejemplo, se alude a la "facción ominosa y sacrílega". Recogido por Castagnino: El teatro..., pág. 427. Es posible encontrar además numerosos ejemplos de la denominación "impíos unitarios". Véanse documentos citados por Abad de Santillán: Historia argentina, pág. 285; Lynch: Rosas..., pág. 214; y Salvatore: "Fiestas...", pág. 50. En opinión de Lynch, el propio Rosas creía firmemente en la impiedad de los unitarios, a quienes consideraba "enemigos de Jesucristo". Lynch: Rosas..., pág. 177. En su proclama del 13 de abril de 1835, por ejemplo, declaró que los unitarios se habían puesto "en guerra abierta con la religión”. En Myers: Orden..., pág. 161.

27 De Angelis, Pedro: "El General Rosas y los Salvajes Unitarios: Artículo tercero", Archivo Americano y Espíritu de la Prensa del Mundo, n. ${ }^{\circ}$ 5, 31 de julio de 1843, págs. 35-37. Recogido por Myers: Orden..., págs. 197-199. Véase además Lynch: Rosas..., pág. 177. 
do a la religión santa del Estado, que habían profanado los impíos salvajes unitarios", afirmaba un texto propagandista de $1842 .{ }^{28}$

El discurso rosista no se limitó a calificar de "impíos" a los unitarios y a censurar sus medidas anticlericales, sino que llegó a identificarlos con el mismo demonio. La prensa oficial, que ya había hecho circular insistentemente la idea de la irreligiosidad unitaria, contribuyó también a la "demonologización del adversario político", ${ }^{29}$ en su sentido literal de asociar a los unitarios con el propio Satán: en 1842, El Restaurador Federal de Córdoba se refirió a los unitarios como a "estos feroces abortos del infierno"..$^{30} \mathrm{En}$ su sugerente estudio sobre las fiestas federales, Ricardo Salvatore, por su parte, destaca el papel jugado por una celebración rosista, la quema de "Judas unitarios", en la transmisión de esta imagen del enemigo como el "demonio unitario". Salvatore apunta que cada Judas de trapo que iba a ser quemado contaba con carteles en los que, además de identificarse con un unitario célebre, reconocía, en primera persona, ser un "enemigo de Dios y de los hombres". En dichos carteles se recordaba además que fue Judas quien "vendió a nuestro redentor Jesús". ${ }^{31}$

La imagen de la impiedad unitaria se enfrenta directamente a la estrecha identificación del régimen rosista con el catolicismo, al menos en el plano retórico. ${ }^{32} \mathrm{Tal}$ identificación fue posible a través de leyes, discursos y celebraciones que insistían en el carácter católico del régimen y en la defensa de la "religión santa del Estado": celebraciones como las quemas de Judas unitarios, en las que el límite entre lo religioso y lo político nunca fue muy nítido; discursos con alusiones frecuentes al Todopoderoso y leyes que propugnaban la protección de la religión católica. ${ }^{33}$ La oposición entre la impiedad unitaria y la religiosidad rosista permitirá la conversión

28 Rasgos biográficos de la vida pública del Brigadier General Don Juan Manuel de Rosas, págs. XXXIV-XXXV. En Myers: Orden..., págs. 301-303.

29 Según la expresión de Salvatore: "Fiestas...", pág. 60.

30 En el n. ${ }^{\circ}$ 47, marzo de 1842, págs. 192-193. Recogido por Myers: Orden..., págs. 286-287.

31 Salvatore: "Fiestas...", pág. 48. Más adelante volveremos a ocuparnos de estas celebraciones.

32 "No se perdía ocasión para identificar al federalismo con la religión", apunta Lynch: Rosas..., págs. 177-178. Mientras tanto, Myers reconoce que "Rosas identificaría a su gobierno con la causa de la ortodoxia católica", aunque señala también que la Iglesia se encontraba subordinada al estado secular rosista y que, de igual modo, los elementos cristianos tuvieron "una posición subordinada" en la economía general del discurso. Myers: Orden..., págs. 85-92.

33 Véase, por ejemplo, la proclama de Rosas del 13 de abril de 1835: "La causa que vamos a sostener es la causa de la religión (...): es causa recomendada por el Todo-Poderoso: él dirigirá nuestros pasos, y con su especial protección nuestro triunfo será seguro". Myers: Orden..., págs. 161-163. Consúltese asimismo la ley en la que Rosas es nombrado gobernador en marzo de 1835. Myers: Orden..., pág. 126. 
simbólica del enfrentamiento con los unitarios en un choque entre las fuerzas del Bien y del Mal, en una guerra santa, especialmente una vez demonizada la figura del enemigo unitario. ${ }^{34}$

"Estamos luchando con hombres que desconocen todo principio moral", señalaba un periódico en 1831, refiriéndose a los unitarios. ${ }^{35}$ Esta frase ilustra otro rasgo atribuido por la retórica rosista a sus enemigos: la inmoralidad, una característica sin duda relacionada con otras que ya hemos visto, como la impiedad o la promoción del desorden. Pruebas de la falta de moral de esta facción eran la ambición sin límite, el desprecio por el honor o sus intentos por corromper a la juventud, atrayéndola hacia posiciones unitarias. Sáinz de Cavia se lamentaba en 1830 porque "los parricidas de diciembre y sus sectarios han sabido hacer entrar en sus intereses a los jóvenes irreflexivos, que por desgracia son los más." ${ }^{36} \mathrm{Al}$ igual que ocurre con otros elementos de la imagen rosista del unitario, la inmoralidad es un rasgo directamente opuesto a uno de los principios que, según la retórica oficial, fundaban el régimen de Rosas: la virtud. ${ }^{37}$

La "conspiración unitaria" es otro elemento recurrente en el discurso que el rosismo construyó acerca de su enemigos. Su relación con la idea de traición, que veremos a continuación, es clara: la conspiración sería la preparación secreta de aquélla, una amenaza constante y, sobre todo, oculta. Jorge Myers confiere un carácter central a este rasgo dentro no sólo de las imágenes atribuidas a los unitarios sino del conjunto de la retórica rosista.

34 Salvatore hace referencia a la idea de guerra santa y a la amenaza de las fuerzas del Mal: "La Federación se pensó como una gran familia de hermanos unidos en guerra santa contra sus enemigos, los unitarios". Salvatore: "Fiestas...", págs. 60-61 y 65.

35 "Política", La Argentina, Libro II, n. ${ }^{\circ}$ 6, 17 de julio de 1831. Recogido por Myers: Orden..., pág. 291. Años después, Pedro de Angelis señalaba que los unitarios "no tardaron en sobreponerse a cualquiera consideración, y hacer alarde de su inmoralidad, rasgo característico de su carácter". De Angelis: "El General Rosas y los Salvajes Unitarios: Artículo sexto", Archivo Americano y Espíritu de la Prensa del Mundo, n. ${ }^{\circ}$ 8, 31 de octubre de 1843, págs. 104-107. En Myers: Orden..., págs. 201-202. El propio Rosas, en su proclama del 13 de abril de 1835, se refirió a los miembros de esta facción como a "hombres corrompidos" que han "introducido por todas partes el desorden y la inmoralidad”. Ibid., págs. 161-163.

36 Sáinz de Cavia, Feliciano: "Política: remedios a nuestros males", El Clasificador, n. ${ }^{\circ} 11,29$ de julio de 1830. En Myers: Orden..., págs. 211-214. Salvatore ha señalado el importante papel atribuido a la mujer en el proceso de "seducción hacia la causa enemiga". Salvatore: "Expresiones...", pág. 219. Sobre la ambición de estos hombres de "pasiones insaciables", véase, por ejemplo, Rasgos biográficos de la vida pública del Brigadier General Don Rosas..., págs. X-XII. En Myers: Orden..., págs. 273-274. Se apunta, además, que a los unitarios "se los describía como hombres sin familia y sin honor", con una "supuesta aversión al matrimonio" y "se sugería su carácter de mancilladores del honor de jóvenes de buena familia”, pág. 56.

37 Myers: Orden..., págs. 45, 50 y 74, por ejemplo. Véase además Myers: "Las formas complejas del poder...", pág. 94. 
Siguiendo modelos ciceronianos o salustinianos, el rosismo habría adoptado la imagen clásica del conspirador aristocrático antirrepublicano, siendo la figura de Catilina el arquetipo. ${ }^{38}$ Sea cual sea el origen de esta imagen y su peso relativo dentro de la retórica anti-unitaria del rosismo, no cabe duda de su ubicuidad. Son frecuentes las alusiones a las "intrigas", a las "maquinaciones" o a la "conjuración" unitaria en múltiples documentos. Así, en 1835, el propio Rosas hacía referencia en una proclama a "los medios ocultos y nefandos de que se vale el espíritu de conspiración", y a "unos manejos disfrazados de mil modos y cubiertos siempre con el velo del sigilo". ${ }^{39}$

Aunque la atribución de esta característica al bando enemigo fue constante a lo largo de todo el periodo rosista, es posible que esta imagen cobrara mayor fuerza tras el descubrimiento de distintas conspiraciones fallidas contra Rosas atribuidas a los unitarios: en 1839 la de Maza, o en marzo de 1841 la de la "máquina infernal" (un artilugio mecánico destinado a matar al dictador). ${ }^{40}$ No es casualidad que el teatro, uno de los principales focos de propaganda anti-unitaria, accesible además a toda la población, programara asiduamente en esos difíciles años obras como El arte de conspirar, de Larra, o La conjuración de Venecia, de Martínez de la Rosa. ${ }^{41}$ Aunque aludieran a otro tiempo y otro lugar, podía hacerse fácilmente una lectura aplicada al presente que contribuyera eficazmente a fortalecer el discurso anti-unitario oficial.

La idea de la conspiración unitaria es inseparable de la visión que vincula a este grupo con la masonería. ${ }^{42}$ Es frecuente encontrar el apelativo "logistas" referido a los unitarios o menciones a las "logias infernales" en las que el enemigo prepara en secreto sus crímenes. Además, el discurso rosista se refirió a los miembros de esta facción con fórmulas como "viles masones", "logistas revoltosos" o "inmundos unitarios logistas". ${ }^{43}$ A título

38 Myers: Orden..., págs. 52-54. El análisis de Myers presta quizá demasiada atención a la figura de la conspiración catilinaria dentro del conjunto de la retórica anti-unitaria, relegando otros rasgos atribuidos a esta facción a una posición secundaria.

39 Myers: Orden..., págs. 161-163. Consúltese, además, Lynch: Rosas..., págs. 195-196 y 215.

40 Myers: Orden..., págs. 196 y 222, respectivamente.

41 La primera sirvió incluso para inaugurar el Teatro de la Victoria, con la presencia de la mujer e hija de Rosas. Castagnino: El teatro..., págs. 333-345. Años después, en 1845, un momento en el que la tensión se había relajado, se representaría La conspiración descubierta. Ibid., pág. 443. Tengamos en cuenta lo que subraya Castagnino: el teatro, "accesible a todo el pueblo", se convirtió durante el rosismo "en la principal diversión pública". Ibid., págs. 20-21.

42 Lynch atribuye este punto de vista al propio Rosas. Lynch: Rosas..., pág. 151.

43 Véanse Salvatore: "Fiestas...”, pág. 50; Lynch: Rosas..., pág. 212; y González Bernaldo, Pilar: "Pedagogía societaria y aprendizaje de la Nación en el Río de la Plata", en Annino, Antonio (et al.): De los Imperios a las Naciones: Iberoamérica, Ibercaja, Zaragoza, 1994, págs. 451-469. Véase pág. 465. 
de ejemplo, veamos un texto publicado en El Relámpago (1833) en el que aparece claramente la identificación entre unitarismo, conspiración y masonería:

Las sociedades secretas han causado la ruina del país. (...) Todo el mundo sabe que estas sociedades son las logias masónicas, y nadie ignora que el infortunado Dorrego fue víctima de sus venganzas. La facción unitaria (...) tramó la muerte de aquel digno ciudadano (...). Antes y después de aquella época desgraciada, todas las conspiraciones, todos los sacudimientos políticos que ha sufrido el país, han sido obra de las logias. ${ }^{44}$

El resultado de las acciones conspirativas era la traición. No podía faltar, por tanto, la imagen de los "traidores unitarios", enemigos de la Independencia vendidos a las potencias extranjeras. ${ }^{45}$ Esta imagen, sin duda fundamental, cobra una especial fuerza en dos momentos concretos. El primero es el periodo de la alianza, iniciada en 1839, entre los emigrados políticos opuestos a Rosas (fueran unitarios o no) y las potencias europeas. Lavalle y Rivera pasan a personificar la traición de los unitarios, quienes, "vendidos al oro francés", se habrían convertido en unos "esclavos de los orgullosos franceses". ${ }^{46}$ El segundo momento en el que se intensifica esta imagen es el de la alianza entre Brasil, Uruguay y Entre Ríos, desde mayo de 1851 hasta el final del régimen de Rosas. Urquiza pasa a ser el símbolo máximo de la traición, "el loco traidor salvaje unitario Urquiza", esta vez "vendido al oro brasileño", ${ }^{47}$

La idea de la traición unitaria fue difundida con vigor por medios muy diversos. La referencia a este elemento del discurso rosista en la prensa del régimen fue constante. Pedro de Angelis, por ejemplo, destacaba en 1847 cómo los unitarios "se han prostituido al extranjero brindándole la independencia de su país", 48

La quema de Judas unitarios, ya citada, parece haber sido otro medio muy efectivo por su capacidad de transmitir esta imagen a la totalidad de la

44 “Fuera Carafas”, El Relámpago, n. ${ }^{2}$ 2, 1 de octubre de 1833, págs. 2-3. Recogido por Myers: Orden..., págs. $275-276$.

45 Myers: Orden..., págs. 63-64. Salvatore, por ejemplo, señala que los "unitarios eran presentados como traidores". Salvatore: "Expresiones...", pág. 201.

46 Expresiones citadas por Abad de Santillán: Historia argentina, pág. 319; y por Salvatore: "Fiestas...", pág. 50. Véanse también Lynch: Rosas..., págs. 197-199; y Castagnino: El teatro..., pág. 392.

47 Lynch: Rosas..., págs. 294-298.

48 De Angelis, Pedro: "Dogma Socialista de la Asociación de Mayo: Juicio sobre este libelo", Archivo Americano y Espíritu de la Prensa del Mundo, n. ${ }^{\circ} 32,28$ de enero de 1847. Myers: Orden..., págs. 203-206. Los ejemplos son innumerables. 
población, analfabeta o no. En su trabajo sobre las fiestas federales, Ricardo Salvatore señala la presencia de una abundante simbología de la traición en torno a las figuras unitarias que iban a ser quemadas (febrero de 1845). Judas, el traidor por antonomasia, se convertía en un unitario al adoptar su vestimenta. A las figuras no les faltaba ni "la bolsa con los dineros" ni una nota en la que reconocían ser "el Salvage Unitario Pardejón Rivera, desertor inmundo de la Causa Santa de la Libertad del Continente Americano". En estas celebraciones, pues, la idea de la traición de los unitarios quedaba muy clara. ${ }^{49} \mathrm{Al}$ igual que en otras fiestas federales, en las quemas de Judas, el "enemigo unitario fue representado como un ser que (...) había traicionado a la nación y adoptado el disfraz de los patriotas"..$^{0}$

El teatro porteño tuvo también un papel capital en esta tarea de difundir la idea de la traición unitaria. Como preludio a la representación teatral del 13 abril de 1842, día en el que se conmemoraba el ascenso de Rosas al poder, se cantó un himno en el que podía oírse lo siguiente:

\author{
Con el nombre de Patria en los labios \\ Asolaban su suelo natal \\ Mendigaban auxilio extranjero \\ Para hollar nuestro honor nacional. \\ (...) \\ Libres ya de traidores feroces \\ Argentinos al fin respirad \\ Vuestra patria por manos serviles \\ No veréis otra vez profanar. ${ }^{51}$
}

En el contexto crítico del verano de 1851, se llevan a escena obras que "execran a los traidores", en palabras de Raúl Castagnino. ${ }^{52}$ Piezas que, adaptadas a la situación, aludían a la idea de traición de una u otra forma, como Juan de Borgoña o el traidor a su patria, de Alberto Larroque y Juan sin Pena o el fin de todo traidor, de Miguel García Fernández. La coincidencia es consciente, como el propio Diario de la Tarde reconocía respecto a esta última obra: "La empresa dramática anuncia para el jueves esta pieza notable por la coincidencia de su asunto con la loca y negra traición

49 Salvatore: "Fiestas...", págs. 48-49. El ejemplo del que se vale Salvatore corresponde a un momento concreto (febrero de 1845). No es, sin embargo, un caso aislado. Lynch, por ejemplo, hace referencia a otras quemas de Judas unitarios. Lynch: Rosas..., pág. 177.

50 Salvatore: "Fiestas...", pág. 46.

51 Citado en Castagnino: El teatro..., págs. 410-412. Quienes "Mendigaban auxilio extranjero" eran, evidentemente, los unitarios.

52 Castagnino: El teatro..., pág. 484. 
del pérfido Urquiza". ${ }^{53}$ En otros casos, la coincidencia con la situación política era aún más explícita: El entierro del loco, traidor, salvaje unitario Urquiza, de Pedro Lacasa, consistió en la escenificación, dentro y fuera del teatro, del funeral de este personaje, considerado el máximo traidor unitario. El acto, celebrado en agosto de 1851, finalizó con el degollamiento y la quema de la figura que representaba a Urquiza. ${ }^{54}$

Finalmente, esta imagen de los unitarios, al igual que otras, se difundió a través de la poesía popular de la época. Un buen ejemplo puede ser éste:

\author{
Perros unitarios \\ Vidalita \\ Nada han respetado \\ A inmundos franceses \\ Vidalita \\ Ellos se han aliado..$^{55}$
}

El discurso rosista vinculó esta traición al cosmopolitismo de los unitarios, considerados partidarios de una europeización de la patria a todos los niveles: desde las costumbres a los modelos políticos. De ese modo, según la propaganda del régimen, los unitarios desearían la reanudación del vínculo colonial. ${ }^{56} \mathrm{El}$ europeísmo, el cosmopolitismo y la traición unitaria chocan frontalmente con el americanismo y el patriotismo propugnados por el discurso rosista. ${ }^{57}$ Esta oposición entre cosmopolitismo y patriotismo aparece claramente en los textos de los propagandistas del rosismo:

(...) los individuos dados al cosmopolitismo, generalmente son, además de malos ciudadanos, consumados egoístas (...). Se apartan de lo que deben a su patria, para servir a la humanidad, y el resultado es, que haciéndoseles indiferente una y otra, a ninguna favorecen, y separan de ambas para siempre sus intereses; tan cierto es que el sentimiento patriótico, que el espíritu de nacionalidad encierra un germen fecundo de moralidad, y que su pérdida pervierte el fondo humanitario del hombre (...). ${ }^{58}$

53 Castagnino: El teatro..., pág. 485. El público debió percibir dicha coincidencia con un gran entusiasmo: Adolfo Saldías apunta que durante una de las representaciones de esta obra se intentó ahorcar, sin éxito, a un actor que tenía un gran parecido con Urquiza. Véase asimismo págs. 486 y 577.

54 Castagnino: El teatro..., págs. 487 y 563. Otras obras en la misma línea fueron Los comuneros de Castilla y El guante de Coradino. Véase también Abad de Santillán: Historia argentina, págs. 460-461.

55 La "vidalita" era un tipo de canción que se prestaba a reflejar cuestiones políticas del momento. Abad de Santillán: Historia argentina, pág. 467.

56 Véanse Myers: Orden..., págs. 55 y 65; y Salvatore: "Fiestas...”, pág. 48.

57 Acerca del "sistema americano" del rosismo, véase Myers: Orden..., págs. 58-61 y 70-71.

58 La Gaceta Mercantil, n. ${ }^{\circ} 7733,28$ de agosto 1849. En Myers: Orden..., págs. 285-286. 
En definitiva, el discurso del régimen identificaba al federalismo y al propio rosismo con la patria, a la vez que presentaba a los unitarios como los mayores enemigos de ésta. "Es preciso que todos esos monstruos dejen de existir, cuando menos civilmente, ya que no pueda ser de otro modo, si queremos tener Patria", afirmaba Sáinz de Cavia en 1830, identificando al enemigo con la negación de la patria. ${ }^{59}$ Otros mecanismos empleados para obtener tal identificación fueron, por ejemplo, la quema de Judas unitarios en la conmemoración del nacimiento de la patria o la realización de los "vivas" y los "mueras" en función de la oposición patria/unitarios. En los festejos del día 13 de abril de 1842 se gritaron juntas las siguientes consignas: “ ¡Viva el gran día 13 de abril! ¡Viva el día de la salvación de nuestra querida patria! ¡Mueran los pérfidos asesinos, los inmundos salvajes unitarios!". ${ }^{60} \mathrm{El}$ enemigo unitario se convertiría así, utilizando la expresión de Myers, "en antítesis de lo argentino". ${ }^{61}$

\section{Las funciones del discurso anti-unitario}

Una vez abordado el discurso anti-unitario desde una aproximación eminentemente descriptiva es el momento de interpretar las distintas funciones que desempeñó. El discurso rosista sobre los unitarios permitió, en primer lugar, la "simplificación", "individualización" e "identificación" del enemigo, al menos en el plano simbólico. Como hemos visto, la adjudicación del calificativo de "unitarios" a todos los presuntos enemigos del régimen hizo posible que los distintos grupos enfrentados al rosismo quedaran reducidos a uno, aunque fuera sólo en el terreno discursivo. Mientras tanto, ciertos personajes del momento pasaron a simbolizar a ese único enemigo, al que, además, era posible reconocer por la apariencia física, al menos en teoría. De esta forma, el enemigo dejaba de ser un ente abstracto para convertirse en alguien tan concreto como Lavalle, Rivera o Urquiza.

59 Sáinz de Cavia: "Introducción”, El Clasificador, n. ${ }^{\circ}$ 1, 6 de julio de 1830. Recogido en Myers: Orden y virtud, págs. 209-210. Myers apunta lo siguiente: "Entre fines de los treinta y mediados de los cuarenta, la República, en un proceso tan complejo como ambiguo, pasó a ser identificada exclusivamente con el Partido Federal —y, más aún, con el rosismo”. Myers: Orden..., pág. 101. Véase también Salvatore: "Expresiones...", pág. 194, n. 10.

60 Citadas en el Diario de la Tarde, 18 de abril de 1842. Castagnino: El teatro..., pág. 407. Véanse asimismo págs. 365 y 390. Acerca de la quema de Judas unitarios en la conmemoración del nacimiento de la patria, véase Salvatore: "Fiestas...", pág. 52.

61 Myers: Orden..., pág. 55. 
La quema de una figura vestida de unitario representando a uno de estos caudillos, por ejemplo, permitía que la población identificara con precisión a los enemigos de la patria, como ha señalado Salvatore. ${ }^{62} \mathrm{Al}$ hacerse más sencilla, la representación del unitario se convertía, posiblemente, en un herramienta más eficaz.

El discurso anti-unitario jugó un rol decisivo en la justificación del sistema rosista, tanto si nos referimos a éste en su conjunto como si aludimos a aspectos más particulares. A pesar de su inmenso poder, Rosas no pudo prescindir de un discurso legitimador que justificara su régimen y generara cierto consenso entre la población. En opinión de Myers, el "Restaurador de las Leyes" era consciente de que para mantenerse en el poder algún tiempo debía combinar las medidas coercitivas con otras destinadas a la obtención de cierto apoyo social. ${ }^{63}$ Dos rasgos modernos como la voluntad general y la opinión pública —expresión de aquélla— debían ser tenidos en cuenta como "fuentes legitimadoras de poder" ${ }^{64}$

La retórica anti-unitaria, pues, permitió justificar la propia existencia del régimen en general y de los poderes excepcionales de Rosas en particular. El proceso de legitimación se repitió de forma muy similar en 1829 y en 1835, las dos ocasiones en las que Rosas accedió al poder. En los dos casos, el enemigo unitario fue considerado por la propaganda rosista el único responsable de los innumerables males que asolaban el país. Ante esta peligrosa situación, era necesario un poder fuerte que hiciera frente al caos. De esta forma, la llegada de Rosas al gobierno de Buenos Aires, investido con facultades extraordinarias, fue presentada como la única alternativa posible a la anarquía. ${ }^{65}$ En 1830, Feliciano Sáinz de Cavia afirmaba lo siguiente:

Pero la razón jefe que hace indispensable las facultades extraordinarias, y las medidas que nosotros hemos propuesto, para salvar la patria de los peligros que la rodean

62 Según este autor, "las quemas de judas tienen un valor didáctico: nombrar y reconocer al enemigo, poner caras y nombres propios al demonio que amenazaba destruir la independencia y la tranquilidad de la república." Salvatore: "Fiestas...”, pág. 49.

63 Myers: "Las formas complejas del poder...", pág. 96.

64 Véase González Bernaldo: "El levantamiento de 1829”, págs. 173-176. Myers señala al respecto que "en un contexto en que la soberanía había pasado a residir, al menos en teoría, en el pueblo, la eficacia de la acción de gobierno del rosismo venía a depender, al menos en parte, del grado de legitimidad que supiera conquistar a ojos de esa suprema instancia refrendataria de la nueva concepción republicana del poder que era la 'opinión pública"”. Myers: "Las formas complejas del poder", pág. 97.

65 Lynch: Rosas..., pág. 191. 
(...) es la urgente necesidad que hay de salvar por momentos el orden interno de la provincia, amenazado de próxima subversión. ${ }^{66}$

Estos argumentos se vieron reforzados por unos asesinatos políticos que precedieron cada uno de los dos ascensos de Rosas al poder: el de Dorrego (diciembre de 1828) y el de Quiroga (febrero de 1835). Naturalmente, ambos crímenes habían sido atribuidos a los unitarios. ${ }^{67}$

Tras ser elegido gobernador de la provincia por segunda vez, Rosas pronunció un discurso que, además de resumir gran parte de la representación de los unitarios, ilustra a la perfección cómo la retórica anti-unitaria fue utilizada para justificar su régimen:

Ninguno de vosotros desconoce el cúmulo de males que agobia a nuestra amada Patria, y su verdadero origen. - Ninguno ignora que una facción numerosa de hombres corrompidos, haciendo alarde de su impiedad, de su avaricia, y de su infidelidad, y poniéndose en guerra abierta con la religión, la honestidad y la buena fe, ha introducido por todas partes el desorden y la inmoralidad; ha desvirtuado las leyes, y hécholas insuficientes para nuestro bienestar; ha generalizado los crímenes y garantizado su impunidad; ha devorado la hacienda pública, y destruido las fortunas particulares; ha hecho desaparecer la confianza necesaria en las relaciones sociales, y obstruido los medios honestos de adquisición, en una palabra, ha disuelto la sociedad, y presentado en triunfo la alevosía y la perfidia.

La experiencia de todos los siglos nos enseña que el remedio de estos males no puede sujetarse a formas, y que su aplicación debe ser tan pronta y expedita, y tan acomodada a las circunstancias del momento, cuanto que no sólo es imposible prever todos los medios ocultos y nefandos de que se vale el espíritu de conspiración, sino también fijar reglas de criterio legal para unos manejos disfrazados de mil modos, y cubiertos siempre con el velo del sigilo.

No queda, pues, otro arbitrio, que oponerles la honradez, el patriotismo y la asidua vigilancia de los buenos ciudadanos, apoyados en la fuerza de un poder extraordinario, cuya acción no sea fácil eludir. ${ }^{68}$

Una vez estabilizado el poder rosista, la retórica anti-unitaria seguía siendo muy necesaria para justificar las políticas del régimen. La idea de la constante amenaza unitaria, por ejemplo, era imprescindible para legitimar

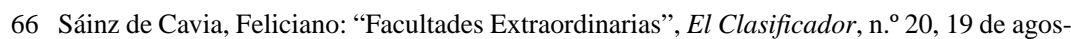
to de 1830, pág. 2. Recogido por Myers: Orden..., págs. 215-216. Poco antes, el mismo autor había defendido un argumento similar: "La H. Representación de la provincia se ha penetrado sin duda de la difícil y peligrosa posición en que nos hallamos, cuando ha resuelto crear un poder dictatorial, que nos salve de esta crisis espantosa." Sáinz de Cavia: "Política: remedios a nuestros males", El Clasificador, n. ${ }^{\circ} 11,29$ de julio de 1830. Recogido por Myers: Orden..., págs. 211-214.

67 Lynch: Rosas..., pág. 158.

68 Proclama del 13 de abril de 1835. Recogida por Myers: Orden..., págs. 161-163. 
el mantenimiento de las facultades extraordinarias en manos de Rosas ${ }^{69}$ Fue también un argumento decisivo para el sostenimiento del esfuerzo bélico y para rechazar la necesidad de una organización constitucional: mientras un grupo de traidores unitarios conspirara sin cesar, amenazando la seguridad de la República, sólo la derrota del enemigo en cada una de las provincias podía ser considerada una prioridad. ${ }^{70}$

Era conveniente además justificar la durísima represión ejercida por el régimen contra aquéllos que recibían la etiqueta de "unitarios", lo fueran o no. ${ }^{71}$ El carácter extremo de la representación de los unitarios en el discurso rosista facilitaba la legitimación de la violencia, siendo especialmente útil para tal justificación la imagen referida al salvajismo del enemigo. ${ }^{72}$ Según este punto de vista, las atrocidades cometidas por esta facción hacían que los métodos represivos del régimen fueran aceptables: contra el salvaje unitario, cualquier condena era adecuada. En esta misma línea, en 1842, El Restaurador Federal de Córdoba rechazaba tajantemente la posibilidad de perdonar al enemigo, ya que

no puede cada un individuo [sic] disponer de los derechos ajenos, y perdonando a los salvajes perdonaríamos las ofensas hechas al público, es muy sabido que seríamos responsables ante Dios, la Patria y los hombres, de los nuevos males que estos pertinaces enemigos causarían a la sociedad y al país.

Según el mismo artículo, el ejemplo de Jesucristo enseñaría a "detestar, perseguir, y exterminar a los salvajes unitarios; a esta raza de víboras, en cuya entraña sólo se abrigan las pasiones más violentas e inno-

69 Todavía en 1844, Sáinz de Cavia afirmaba que el General Rosas estaba “investido con facultades extraordinarias por las peligrosas y graves circunstancias del país". Sáinz de Cavia, Feliciano: "Cartas sobre la América del Sud (continuación)", La Gaceta Mercantil, n. ${ }^{\circ}$ 6091, 23 de enero de 1844. En Myers: Orden..., pág. 230.

70 Véanse Goldman, Noemí y Salvatore, Ricardo: "Introducción”, en Goldman y Salvatore (eds.): Caudillismos rioplatenses, pág. 169.

71 En opinión de Myers, la naturaleza "unanimista” del discurso rosista hacía necesaria la justificación de la exclusión. Por ello, "el discurso rosista se vio obligado a perseguir la meta quizás un tanto quimérica de abarcar a todos aquellos grupos sociales en su seno - o al menos de justificar en términos propios de una retórica 'republicana' la expulsión de aquellos grupos cuya inclusión revelaba ser imposible o indeseable." Myers: “Las formas complejas del poder”, pág. 93.

72 Véase, por ejemplo, Lynch: Rosas..., págs. 205 y 220-221. En otros casos, podía recurrirse también a las ideas de traición o conspiración, como hace esta canción del ejército: "Al que con salvajes / Tenga relación / La verga y el degüello / Por esta traición; / Que el santo sistema / De Federación, / Les da a los salvajes / violín y violón." Con "violín y violón" se hace alusión a la práctica del degüe1lo. Acerca de la legitimación de "los medios violentos de la política", consúltese Salvatore: "Fiestas...", pág. 49. En una ocasión, por ejemplo, Rosas afirmó que la persecución a los unitarios estaba justificada por "las circunstancias extraordinarias en que han colocado a este desgraciado país las crueldades de sus bárbaros enemigos”. Citado en Lynch: Rosas..., pág. 219. 
bles". ${ }^{73}$ La maldad de los enemigos servía también para justificar otras acciones en su contra, además de la pura violencia física. En septiembre de 1840, como reacción a la invasión de Lavalle, Rosas firmó un decreto de confiscación de las propiedades unitarias: "Preciso es que la república sea depurada de tan inmundos traidores (...). En sus personas y en sus fortunas deben sentir las terribles consecuencias de su iniquidad, su alevosía, de su salvajismo". ${ }^{74}$

Existen indicios para pensar que el discurso rosista intentó dar a la represión anti-unitaria una apariencia de normalidad a través de la celebración de actos diversos que convertían la muerte de los enemigos en algo cotidiano y natural, al menos en el plano simbólico. Esto ocurría, por ejemplo, en las ya citadas quemas de Judas unitarios, pero también en representaciones teatrales como El entierro del loco, traidor, salvaje unitario Urquiza (1851), o en un número anunciado para la función del 23 de diciembre de 1841 en el que se escenificaría "el duelo de un federal con un salvaje unitario en el que el primero degollará al segundo"..$^{75}$

El discurso anti-unitario, especialmente una vez simplificada la figura del enemigo, permitía además dar una cierta cohesión a los diferentes grupos que apoyaban al régimen rosista. Un discurso dirigido a sectores sociales tan diversos necesitaba, sin duda, un "enemigo común" que contribuyera a limar las tensiones producidas por el distinto origen social, racial o geográfico. ${ }^{76} \mathrm{El}$ "discurso oficial de igualitarismo y unanimismo", ${ }^{77}$ hacía necesario, pues, el uso de una retórica anti-unitaria que, unida a otros elementos, permitiera restar visibilidad a las diferencias sociales, "nivelándolas temporariamente, pero sin erradicarlas", si utilizamos la expresión de Salvatore. ${ }^{78}$ La figura de los unitarios juega, por tanto, el

73 “Cuaresma”, El Restaurador Federal, n. ${ }^{\circ}$ 47, Córdoba, marzo de 1842, págs. 192-193. Recogido por Myers: Orden..., págs. 286-287. Cursiva en el original.

74 Citado en Lynch: Rosas..., pág. 220. La cursiva es mía. Acerca de dicho decreto, ver pág. 203.

75 Citado por Castagnino: El teatro..., pág. 405.

76 En opinión de Myers, el discurso rosista "se distinguió por su notable capacidad de interpelar a sectores sociales grandemente dispares". Myers: Orden..., pág. 22. Véase también Myers: "Las formas complejas del poder...”, págs. 93 y 96.

77 Salvatore: "Expresiones...”, pág. 222. El término "unanimismo" es empleado también por Myers: "Las formas complejas del poder", págs. 91-93. La expresión fue acuñada por M. Ternavasio para describir el régimen de Rosas. Ternavasio, Marcela: "Entre la deliberación y al autorización. El régimen rosista frente al dilema de la inestabilidad política", en Goldman y Salvatore (eds.): Caudillismos rioplatenses..., págs. 159-188.

78 Entre esos otros elementos que contribuyen a aminorar las diferencias sociales, Salvatore señala la uniformidad del vestido o el "unanimismo" de las expresiones. Salvatore: "Expresiones...", pág. 191. 
importante papel de "enemigo común", la referencia negativa imprescindible para hacer posible —o reforzar- la unión de cualquier colectivo. Como ejemplo, y refiriéndose a las fiestas federales, Ricardo Salvatore apunta que gritar repetitivamente los nombres de los enemigos unitarios en larguísimos brindis "ayudaba a consolidar a la comunidad política (los vecinos federales) frente al enemigo común". ${ }^{79}$ En este mismo sentido, el propio Rosas parece haber sido consciente de la función cohesiva del discurso anti-unitario. En 1847, al justificar en una conversación con William MacCann la utilización del elemento más llamativo de dicho discurso - el lema "¡Viva la Confederación Argentina! ¡Mueran los Salvajes unitarios!"-, el dictador sostuvo que tal expresión no era otra cosa que un "lema de hermandad", "a la vez que lo ilustraba dándome un enérgico abrazo", relata MacCann. ${ }^{80}$

Antes de tratar de lleno una última pero relevante función desempeñada por el discurso anti-unitario, veamos, a modo de introducción, el siguiente texto de Augustin Redondo:

S'interroger sur l'Autre, c'est aussi s'interroger sur soi-même. Altérité et identité (individuelle et collective) sont les deux pôles complémentaires d'une même réalité humaine. L'Autre est le miroir inversé de soi-même, il est celui qui permet de construire sa propre identité, que le regard que l'on porte sur lui soit celui des dominants ou des dominés. ${ }^{81}$

Siguiendo el punto de vista que sostiene la imposibilidad de entender la identidad sin conocer la alteridad, puede afirmarse que la imagen que el discurso rosista construyó acerca del enemigo unitario actuó como un referente negativo que permitió, por oposición, la definición y el fortalecimiento de un sentimiento de identidad colectiva. Se produce así un fenómeno similar a otros sobre los que José Carlos Chiaramonte ha llamado la atención. Aludiendo a la construcción de identidades "en negativo" en el Río de la Plata colonial, este autor ha señalado, por ejemplo, que "toda identidad remite a una oposición, faz inseparable del proceso de su construcción". ${ }^{82}$ Ricardo Salvatore también ha prestado atención a estas cues-

79 Salvatore: "Fiestas...", pág. 58.

80 Anécdota citada por Lynch: Rosas..., pág. 172.

81 Redondo, Augustin: "Introduction", en Redondo, Augustin (dir.): Les représentations de l'Autre dans l'espace ibérique et ibéro-américain, Presses de la Sorbonne Nouvelle, París, 1991, pág. 11. François-Xavier Guerra, entre otros, sostiene un punto de vista similar. Ha afirmado, por ejemplo, que "la identidad propia se afirma, o se inhibe, en relación con el 'otro'." Guerra, François-Xavier: "Introducción”, en Annino (et al.): De los Imperios a las Naciones..., pág. 12. 
tiones en su artículo acerca del reclutamiento militar en la era de Rosas, destacando la importancia de los juegos de opuestos en la creación de identidades colectivas. ${ }^{83}$ Llega a afirmar que a través de los diversos símbolos rosistas "se trató de construir una identidad protonacional en los paisanos con base en la oposición a los unitarios." ${ }^{4}$

Sea el sentimiento de pertenencia del tipo que sea, no hay duda de que se fundó en la oposición a la imagen de los unitarios que el discurso rosista había creado. Hemos visto cómo esta representación se construyó — se imaginó- a partir de una serie de rasgos opuestos frontalmente a los valores y características que, según el rosismo, deberían definir la identidad colectiva. Surge así un "imaginario oposicional", ${ }^{85}$ en el que el orden se enfrenta al salvajismo y a la anarquía; la religiosidad a la impiedad; la virtud a la inmoralidad y el patriotismo a la traición. En definitiva, la patria a la "antipatria".

Otra muestra del papel jugado por la imagen simbólica del enemigo como refuerzo negativo de la identidad mayoritaria se encuentra en la definición cotidiana de "patriota" (o de "federal", dos términos considerados equivalentes en este momento). Los ejemplos recogidos por Ricardo Salvatore en "Expresiones federales" sugieren que, en gran parte, la pertenencia al colectivo ideal de referencia se demostraba a través de un mecanismo negativo: el patriota (o el federal) debía mostrar no ser unitario. Para lograrlo no bastaba oponer el aspecto federal al aspecto unitario, como

82 Chiaramonte: Ciudades, provincias, Estados..., pág. 73. La expresión "sentimiento de identidad colectiva" está tomada del mismo autor (p. 73). En la misma línea, Chiaramonte manifiesta lo siguiente respecto al choque de identidades en el periodo colonial: "podemos observar que se era español frente al resto del mundo, español americano frente a lo español peninsular, rioplatense frente a lo peruano, provinciano frente a lo capitalino, porteño frente a lo cordobés... La dominación española no dejó otra cosa que un mosaico de sentimientos de pertenencias grupales, con frecuencia manifestadas como colisión de identidades", ver pág. 62.

83 Según Salvatore, el ejército "creó dicotomías culturales que sirvieron para definir la identidad de los paisanos. Para estancieros, comandantes militares y políticos, las barracas, los fortines, y las campañas proveían espacios donde se articularon dualidades fundacionales: gaucho/gente decente; nativos/cristianos; unitarios/federales; propietario/vago." Más adelante, afirma lo siguiente: "Los cuarteles, espacio para la creación de identidades colectivas, (...) integraron gentes de diverso origen y les proveyeron de polaridades discursivas que servían para definir nuevas identidades (peones de campo, cristianos, federales, nacionales).” Salvatore: "Reclutamiento militar...", págs. 42-45.

84 Salvatore: "Reclutamiento militar...", pág. 43. No es éste el momento de entrar en el debate acerca del carácter de estos sentimientos de identidad. Para ello, consúltense, por ejemplo, Chiaramonte: Ciudades, provincias, Estados; Wasserman: "La Generación de 1837”; y González Bernaldo, Pilar: "La 'identidad nacional' en el Río de la Plata post-colonial. Continuidades y rupturas con el Antiguo Régimen”, Anuario IEHS, n. ${ }^{\circ}$ 12, UNCPBA, Tandil, 1997, págs. 109-122.

85 Expresión tomada de Salvatore: "Reclutamiento militar", pág. 44. 
hemos visto, sino que tenía que manifestar hacia el enemigo un odio extremo y, sobre todo, visible, expresado en los "mueras" y en los cada vez más virulentos calificativos que solían preceder al término "unitario". Salvatore apunta, por ejemplo, que los soldados veteranos, al "nombrar al enemigo, usaban largos epítetos - 'inmundos asquerosos salvages unitarios' - que reafirmaban su filiación política." ${ }^{86}$ Para ser un patriota federal era por tanto obligado ser en primer lugar anti-unitario ${ }^{87}$

Por otro lado, la representación estereotipada de los unitarios es una referencia negativa especialmente necesaria en un momento - primera mitad del siglo XIX - en el que el mundo de los sentimientos de pertenencia colectiva distaba de ser simple. Tal complejidad era debida en su mayor parte a la coexistencia en el espacio rioplatense de muy distintas identidades políticas. Aquellas de carácter local o provincial, más tradicionales, convivían con la identidad americana, la rioplatense, la argentina e incluso con el nuevo sentimiento de pertenencia a la patria republicana. ${ }^{88}$ A tal confusión se añadía la ambigüedad de los términos relativos a dichas formas de pertenencia. Cierta flexibilidad permitía que, según el contexto, una expresión concreta adquiriera significados diferentes. Bajo Rosas, un término como "patria", por ejemplo, podía aludir a realidades geográficas muy diversas según la ocasión en que fuera empleado. ${ }^{89}$ Esta complejidad, unida a la imprecisión en los límites, fueran éstos geográficos, culturales o

86 Salvatore: "Expresiones...", pág. 208. El mismo autor apunta que en diversas peticiones escritas a Rosas, los solicitantes casi nunca "apelaban al federalismo de apariencias o de palabras, limitándose a las formas de expresión más cercanas a los hechos — bienes y servicios- y a los sentimientos —odio a los unitarios, veneración a Rosas.” Ibid., pág. 209. La cursiva es mía.

87 En palabras de Salvatore, los que "nunca se manifestaban por uno u otro partido, dejaban crecer sospechas sobre su verdadera filiación política." "Expresiones...”, pág. 219. El siguiente párrafo ilustra también la necesidad de definirse como no-unitario: "quien no se defendía de la acusación de 'unitario' permitía las sospechas y, sobre todo, no frenaba la circulación de los rumores que, a la larga, definirían su futuro. Los insultos, en este proceso de identificación de adhesiones, jugaban un papel importante. Las palabras 'Salvaje Unitario' lanzadas en un espacio público contra algún vecino constituían un insulto y, por tanto, su uso fue origen de numerosas querellas judiciales y de peleas." Ibid., pág. 204. Véase asimismo Lynch: Rosas..., pág. 172.

88 La coexistencia entre diferentes identidades no era algo nuevo. Para finales del periodo colonial, Chiaramonte apunta que "los habitantes del Río de la Plata comparten diversos sentimientos de pertenencia: el correspondiente a la nación española — en parte de ellos muy debilitado— el de español americano, y el regional, regionalidad frecuentemente reducida a su núcleo urbano". Chiaramonte: Ciudades, provincias, Estados, pág. 75. Consúltense también Wasserman: "La Generación de 1837”, págs. 10 y 33; y González Bernaldo: "La “identidad nacional...”, págs. 114-115.

89 Salvatore apunta lo siguiente: "La República Federal imaginada por Rosas y sus seguidores dejaba mucho sin ser definido. Los límites territoriales a los cuáles los términos patria y nación debían referirse, por ejemplo, eran bastante flexibles, aludiendo a veces al territorio que los líderes de la independencia trataron de convertir en nación, otras veces a la provincia de Buenos Aires, y en ocasiones 
simplemente lingüísticos, dificultaba la definición del "nosotros", haciendo aún más necesaria la existencia de un "enemigo simbólico" nado en la representación del unitario- que facilitara la convivencia entre antiguas y nuevas pertenencias y que contribuyera a definir, por oposición, la propia identidad. Coloquialmente, quizá podría formularse de la siguiente manera: "ya que no podemos saber quiénes somos, sepamos al menos lo que no somos".

\section{A modo de conclusión}

El 3 de febrero de 1852, Juan Manuel de Rosas fue derrotado por Justo José de Urquiza en la batalla de Monte Caseros, cerca de Buenos Aires. Tras refugiarse en la casa del encargado de negocios del Reino Unido, la nave británica Conflict le llevó al exilio en Inglaterra, donde permanecería hasta su muerte en 1877. Con la huida de Rosas acababa el rosismo, una etapa de la historia argentina en la que la propaganda oficial había construido un discurso que presentaba una imagen ideal e irreal del enemigo unitario. Según dicha representación, los unitarios, además de poder ser reconocidos por su aspecto exterior, eran salvajes, impíos e inmorales, promovían la anarquía y conspiraban desde sus logias para traicionar a la patria. Esta representación simbólica del enemigo unitario cumplió una serie de funciones tales como "simplificar" e "individualizar" a los adversarios, justificar el régimen rosista y sus políticas, dar cohesión a la población a través de la imagen de un enemigo común y, finalmente, definir y fortalecer, por oposición, un sentimiento de identidad colectiva, al menos entre aquéllos que, con sus gritos, deseaban larga vida a la Confederación Argentina y muerte a los salvajes unitarios.

\footnotetext{
a territorios más limitados circunscriptos por relaciones familiares y afectivas (la tierra nativa o patria chica). Los términos Confederación y Federación también tenían significados ambivalentes." Salvatore: "Fiestas...", págs. 62-63. Sobre ambigüedades terminológicas, véase también Chiaramonte: Ciudades, provincias, Estados, págs. 78 y 115-116.

90 Los unitarios, en sí, podían ser un enemigo muy real, pero su representación se ubica en el mundo de los símbolos, como ya hemos señalado.
} 